\title{
Collisions between Whales and Fast Ferries around Korean Waters
}

\author{
Kyung-Jun Song \\ Institute of Cetacean Research, University of Ulsan, Ulsan 680-749, Republic of Korea \\ Correspondence should be addressed to Kyung-Jun Song; kjsong329@hanmail.net
}

Received 2 August 2013; Accepted 2 October 2013

Academic Editor: Jakov Dulčić

Copyright (C) 2013 Kyung-Jun Song. This is an open access article distributed under the Creative Commons Attribution License, which permits unrestricted use, distribution, and reproduction in any medium, provided the original work is properly cited.

\begin{abstract}
Although there is heavy maritime traffic around Korean waters, collisions between whales and fast ferries around Korean waters are nearly unknown. A ship strike that was associated with a minke whale occurred near the southeastern part of Tsushima Island along the sailing route of the fast ferry between Korea and Japan on December 16, 2004. It was associated with a fast ferry that runs at a speed of approximately $46.1 \mathrm{kn}(83 \mathrm{~km} / \mathrm{h})$ between Korea and Japan. This individual was certainly seriously injured or killed by this ship strike because large amounts of skin of this individual were attached to the surface of the fast ferry, and also large amounts of blood of this individual spread out in that area. However, fortunately, serious damage did not occur to the mariners and passengers of the ferry, although many passengers were knocked down to the floor of the fast ferry when the fast ferry collided with the minke whale. In addition, a total of 4 records of possible collisions between whales and fast ferries have occurred on the fast ferry route between Korea and Japan between 2004 and 2007. This study is the first formal report on collisions between whales and fast ferries around Korean waters. Although the effect of ship strikes on the survival of cetaceans distributed around Korean waters is not very high at present compared with that of other threats, such as entanglement in fishing gear, ship strikes can pose a significant potential threat to endangered cetaceans such as western gray whales. Therefore, it is necessary to prepare prevention measures for ship strikes for the conservation of cetaceans around Korean waters in the future.
\end{abstract}

\section{Introduction}

Collisions between cetaceans and ships, known as ship strikes, have been continuously reported all around the world $[1,2]$. Furthermore, the frequency of ship strikes has tended to increase in recent years because of the increase in maritime traffic and in the speed of various vessels. A comprehensive review of ship strikes with large whales throughout the world has been made for the first time [1]. According to this investigation, a total of 11 species collided with vessels throughout the world. Among these 11 species, several species such as fin whales, right whales, humpback whales, sperm whales, and gray whales frequently collided with vessels. They also noted that ship strikes have occurred with all types of vessels based on the historical records and a computerized stranding database. On the other hand, according to some studies, a total of 292 large whale individuals collided with vessels between 1975 and 2002 [2].

Although the effect of ship strikes on the population size of cetaceans is not so serious for the majority of cetaceans, it is one of the significant human related threats, including entanglement in fishing gear, particularly to the survival of critically endangered cetaceans like North Atlantic right whales $[3,4]$. For instance, there are only approximately 300 North Atlantic right whale individuals in the total population [5-7], and ship strikes are considered to be the most significant human related threat to the recovery of this population at present $[3,4]$. Similarly, western gray whales, which are one of the most critically endangered cetaceans throughout the world, probably migrate around Korean waters according to a past study [8]. Additionally, many ships such as fast ferries travel around Korean waters. Therefore, it is thought that the possibility of ship strikes that are associated with western gray whales exists, although there has so far been no concrete report on a ship strike on western gray whales.

The purpose of this study is to investigate collisions between whales and fast ferries around Korean waters and to use this information to help prepare prevention measures for ship strikes around Korean waters in the future. 


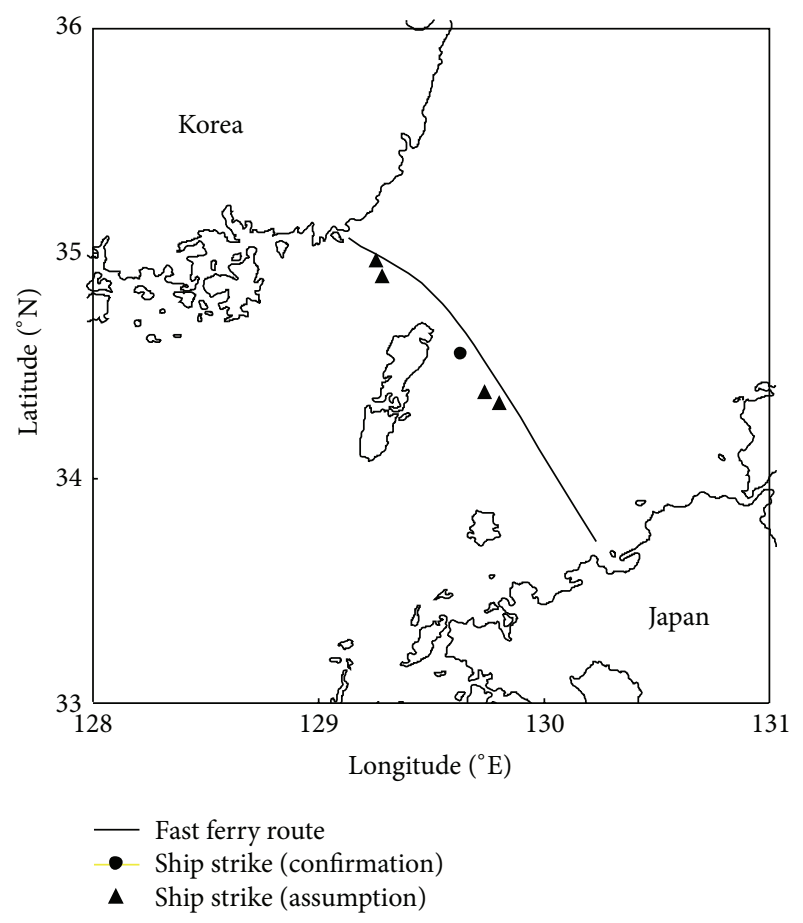

FIgURE 1: Locations of ship strikes on the fast ferry route between Korea and Japan.

\section{Materials and Methods}

The study area is the Korea Strait between Korea (Busan) and Japan (Fukuoka) (Figure 1). Several fast ferries (5-7 navigations per day) operate on this route at an average speed of about 46 knots. The total length of this fast ferry route ranges approximately from 115 to 136 nautical miles $(\mathrm{nm})$. The information in this paper on collisions was obtained from the Mirae Jet Corporation, which is the only high speed vessel corporation operating this route. Collisions on this fast ferry route were reported from 2004 to 2007.

\section{Results}

A ship strike which is associated with a minke whale occurred in the southeastern part of Tsushima Island along the sailing route of a fast ferry between Korea and Japan $\left(34^{\circ} 33^{\prime} \mathrm{N}\right.$, $129^{\circ} 38^{\prime} \mathrm{E}$ ) on December 16, 2004 (Table 1 and Figure 1). It was associated with a fast ferry that runs at a speed of approximately 46 knots $(83 \mathrm{~km} / \mathrm{h})$ between Korea and Japan. A cetacean that collided with this fast ferry on December 16, 2004, was identified as a minke whale through DNA analysis using a biological sample, which was attached to the surface of the ferry when the ship strike occurred, by the Cetacean Research Institute of Korea.

The effect of the ship strike on minke whale could not be determined because this individual was not found after the ship strike occurred. In spite of the lack of information on the fate of this minke whale, this individual was certainly seriously injured or killed by this ship strike because large amounts of skin of this individual were attached to the surface
TABLE 1: Record of a collision between a whale and a fast ferry around Korean waters.

\begin{tabular}{|c|c|}
\hline $\begin{array}{l}\text { Date } \\
\text { (month/day/year) }\end{array}$ & $12 / 16 / 04$ \\
\hline Species & Minke whale \\
\hline Fate of cetacean & Unknown, but mortality assumed \\
\hline Location & $\begin{array}{l}12 \mathrm{~nm} \text { southeast of Daema Island } \\
\text { (Tsushima), Japan }\end{array}$ \\
\hline Coordinates & $34^{\circ} 33^{\prime} \mathrm{N}, 129^{\circ} 38^{\prime} \mathrm{E}$ \\
\hline Vessel type & Fast ferry \\
\hline Vessel size $(\mathrm{m})$ & 23.93 \\
\hline Vessel speed (kts) & 46.1 \\
\hline Vessel damage & $\mathrm{Y}$ \\
\hline Comments & $\begin{array}{l}\text { Vessel struck whale while underway, skin } \\
\text { left on the body of vessel; blood in water } \\
\text { after collision, mortality assumed }\end{array}$ \\
\hline
\end{tabular}

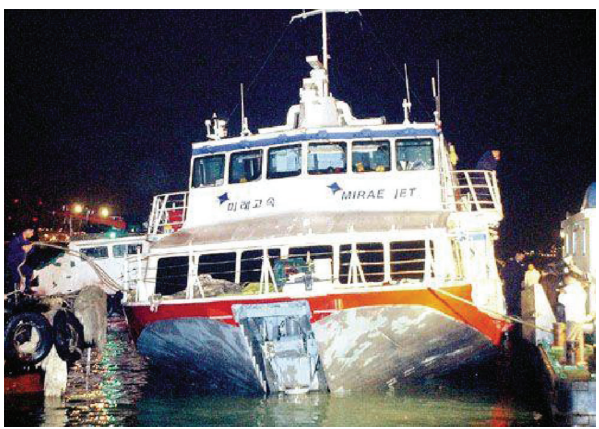

FIGURE 2: Picture of the fast ferry which collided with a minke whale on December 16, 2004.

of the fast ferry, and also a large amount of blood of this individual was spread out in that area. The underwater wing and lower hull of this fast ferry were seriously damaged due to the collision with the minke whale (Figure 2). However, fortunately, serious damage did not occur to the mariners and passengers, although many passengers were knocked down to the floor of this fast ferry when it collided with the minke whale.

In addition, a total 4 records of possible collisions between whales and fast ferries occurred on the fast ferry route between Korea and Japan from 2004 to 2007 (Table 2 and Figure 1). However, the other whales which are associated with the other 4 collisions were not identified because of the lack of information on them. Unfortunately, a possible ship strike that was associated with the killing of one passenger occurred on April 12, 2007.

\section{Discussion}

Although there is heavy maritime traffic around Korean waters, ship strikes around Korean waters were nearly unknown before the investigation of this study. The collision of a fast ferry with a minke whale on December 16, 2004, is the first formally reported ship strike around Korean waters. 
TABLE 2: Summary of collisions between whales and fast ferries on the fast ferry route between Korea and Japan from 2004 to 2007.

\begin{tabular}{|c|c|c|c|c|c|}
\hline Number & $\begin{array}{c}\text { Date } \\
\text { (month/day/year) }\end{array}$ & Latitude & Longitude & Status & Species \\
\hline 1 & $04 / 05 / 2004$ & $34^{\circ} 20^{\prime} \mathrm{N}$ & $129^{\circ} 48^{\prime} \mathrm{E}$ & Assumption & Unknown \\
\hline 2 & $12 / 16 / 2004$ & $34^{\circ} 33^{\prime} \mathrm{N}$ & $129^{\circ} 38^{\prime} \mathrm{E}$ & Confirmation & Minke whale \\
\hline 3 & $04 / 01 / 2005$ & $34^{\circ} 23^{\prime} \mathrm{N}$ & $129^{\circ} 44^{\prime} \mathrm{E}$ & Assumption & Unknown \\
\hline 4 & $04 / 29 / 2005$ & $34^{\circ} 58.4^{\prime} \mathrm{N}$ & $129^{\circ} 15.9^{\prime} \mathrm{E}$ & Assumption & Unknown \\
\hline 5 & $04 / 12 / 2007$ & $34^{\circ} 55.2^{\prime} \mathrm{N}$ & $129^{\circ} 19.8^{\prime} \mathrm{E}$ & Assumption & Unknown \\
\hline
\end{tabular}

On the other hand, the reported ship strikes of minke whales correspond to the minimum estimate of ship strikes around Korean waters because many ship strikes were undetected and also unreported, as pointed out in many studies $[1,2]$. Nevertheless, they clearly and firstly show that ship strikes occur around Korean waters as in other countries all over the world.

Among the 35 species ( 8 baleen whales and 27 toothed whales) that have been reported to inhabit the waters around Korea, at least two species, minke whales and finless porpoises, have been clearly related to ship strikes around Korean waters until now. However, except for these two species, there have been no formal reports on ship strikes which have been associated with other species around Korean waters. On the other hand, 4 possible ship strikes were not counted in the total number of ship strikes around Korean waters because of the lack of exact information on the species associated with these possible ship strikes.

Ship strikes of minke whales are considered relatively common in other studies $[1,2]$. On the other hand, ship strikes with small cetaceans such as finless porpoises are considered uncommon compared with those of large cetaceans. Furthermore, ship strikes with small cetaceans were less frequently reported than those of large cetaceans because of their small size compared with large cetaceans. Based on the information on ship strikes around Korean waters, ship strikes affect cetaceans of various sizes, including minke whales and finless porpoises, around Korean waters. Relatively large cetaceans, such as minke whales, have collided with fast ferries around Korean waters as well as comparatively small cetaceans, such as finless porpoises, both of which have also been cut by the propellers of certain ships and stranded on the shores of Korea. In addition to the reported ship strikes of minke whales and finless porpoises, many cetaceans that are distributed around Korean waters also may be associated with ship strikes because heavy traffic of maritime vessels exists around Korean waters. Therefore, many cetaceans that are distributed around Korean waters also may be exposed to ship strikes in the way that minke whales and finless porpoises are.

Ship strikes also occur around Korean waters as in other parts of the world, although ship strikes around Korean waters are a very occurrence compared with those around other countries $[1,2]$. In addition, ship strikes have occurred around Korean waters before the report on ship strikes in this study, according to the statements of fast ferry crews. Although many unreported ship strikes have occurred, few people have been known to obtain information on the frequency and effect of ship strikes around Korean waters until now because of the absence of obligations to report on ship strikes. Therefore, these unreported ship strikes have been excluded from this study because of the lack of information regarding the evidence of such ship strikes. Thus, it is necessary to obligatorily report ship strikes around Korean waters in the future in order to obtain the exact information on ship strikes.

Some studies have noted that ship strikes are associated with various vessel types and vessel speeds, based on their review of ship strike records throughout the world [1]. A wide range of vessel types, including whale-watching vessels, cargo ships, ferries, navy ships, and passenger ships, are related to ship strikes in the world [1]. These studies have also noted that the most severe and lethal injuries to cetaceans have generally been related to large ships (more than $80 \mathrm{~m}$ ) and fast ships (more than 14 knots) [1]. Around Korean waters, there is heavy maritime traffic and also many fast ferries run at a speed of 46 knots along the fast ferry route between Korea and Japan. Thus, the possibility of ship strikes around Korean waters is relatively high, and it also may be lethal to cetaceans around Korean waters.

The types of injuries to cetaceans by ship strikes generally take two forms, propeller wounds and blunt trauma injuries [1]. Generally, propeller wounds could be easily recognized by investigation of the external expression of such an injury, while blunt trauma injuries are difficult to recognize because of the lack of external expression. Cetacean stranding data from marine mammal stranding programs have provided important information on ship strikes $[1,2]$. In such studies, a large portion of the information on ship strikes is obtained from the cetacean stranding data. Additionally, ship strikes are responsible for a large portion of cetacean strandings. For example, approximately one-third of all fin whale and right whale strandings in certain areas are related to ship strikes [2, 4]. Unfortunately, there has been no systematic investigation to obtain the causes of cetacean stranding around Korean waters. Because of the lack of systematic investigation, a low portion of cetacean stranding records have been related to ship strikes, although a higher portion of cetacean stranding records may in reality be related to ship strikes. Therefore, it is necessary to concretely investigate the causes of cetacean stranding around Korean waters in the future. Furthermore, based on the value of cetacean stranding data, there is a need to maintain and improve the marine mammal stranding program more efficiently. 
Ship strikes around Korean waters could not seriously affect mariner/passenger safety, although many passengers were slightly injured after the collisions, and also the underwater wing and lower hull of this fast ferry were seriously damaged. However, unfortunately, a possible ship strike that was associated with the killing of one passenger occurred on April 12, 2007. Furthermore, a study reported a ship strike that was associated with the killing of a sperm whale and also one passenger in the Canary Islands [9]. In this ship strike, a fast ferry collided with a sperm whale at a speed of 45 knots. Therefore, it is necessary to prepare measures for the occurrences of such situations around Korean waters.

The effect of ship strikes on the survival of cetaceans that are distributed around Korean waters is not high at present, compared with other threats, such as entanglement in fishing gear [10-15]. Among various threats to cetaceans, entanglement in fishing gear is the most significant threat to the survival of cetaceans around Korean waters at present, rather than ship strikes. However, although the effect of ship strikes is not high at present, ship strikes can pose a significant potential threat to highly endangered cetaceans such as western gray whales that probably migrate around Korean waters, because there are only approximately 100 individuals in this population [16]. Therefore, it is necessary to be concerned about potential threats, such as not only entanglement in fishing gear but also ship strikes.

The strategy to reduce ship strikes on slow swimming North Atlantic right whales on the northeast of the USA includes the modification of sailing routes and speeds regulations and is being developed by NOAA Fisheries of USA This strategy for North Atlantic right whales is the only strategy being developed for the prevention of ship strikes in the world. Apart from this strategy for North Atlantic right whales, which are one of the most endangered cetaceans in the world, there is no systematic effort to reduce ship strikes in the world at present. Similarly, because western gray whales are also one of the most endangered cetaceans in the world, and because they have probably migrated around Korean waters where heavy maritime traffic exists, it is necessary to prepare prevention measures for ship strikes around Korean waters.

The following items need to be investigated in the future: (1) the distribution pattern of cetaceans on major sailing routes of fast ferries around Korean waters, (2) the prevention measures for ship strikes around Korean waters, and (3) the relevance between cetacean strandings and ship strikes of cetaceans around Korean waters.

\section{Acknowledgment}

The author wishes to acknowledge the Mirae Jet Corporation for offering the information on ship strikes around Korean waters.

\section{References}

[1] D. W. Laist, A. R. Knowlton, J. G. Mead, A. S. Collet, and M. Podesta, "Collisions between ships and whales," Marine Mammal Science, vol. 17, no. 1, pp. 35-75, 2001.
[2] A. S. Jensen and G. K. Silber, "Large whale ship strike database," NOAA Technical Memorandum NMFS-OPR, U.S. Department of Commerce, Washington, DC, USA, 2004.

[3] S. D. Kraus, "Rates and potential causes of mortality in North Atlantic right whales (Eubalaena glacialis)," Marine Mammal Science, vol. 6, no. 4, pp. 278-291, 1990.

[4] A. R. Knowlton and S. D. Kraus, "Mortality and serious injury in North Atlantic right whales," Journal of Cetacean Research and Management, vol. 2, pp. 193-208, 2001.

[5] A. R. Knowlton, S. D. Kraus, and R. D. Kenney, "Reproduction in North Atlantic right whales (Eubalaena glacialis)," Canadian Journal of Zoology, vol. 72, no. 7, pp. 1297-1305, 1994.

[6] H. Caswell, M. Fujiwara, and S. Brault, "Declining survival probability threatens the North Atlantic right whale," Proceedings of the National Academy of Sciences of the United States of America, vol. 96, no. 6, pp. 3308-3313, 1999.

[7] M. Fujiwara and H. Caswell, "Demography of the endangered North Atlantic right whale," Nature, vol. 414, no. 6863, pp. 537$541,2001$.

[8] H. Kato and T. Kasuya, "Some analyses on the modern whaling catch history of the western North Pacific stock of gray whales (Eschrichtius robustus), with special reference to the Ulsan whaling ground," Journal of Cetacean Research and Management, vol. 4, no. 3, pp. 277-282, 2002.

[9] M. Andre, M. Terada, and Y. Watanabe, "Sperm whale (Physeter macrocephalus) behavioral response after the playback of artificial sound," Report of the International Whaling Commission, vol. 47, pp. 499-504, 1997.

[10] K. J. Song, Population ecological characteristics of minke whales (Balaenoptera acutorostrata) in Korean waters [Ph.D. thesis], Pukyong National University, Busan, Republic of Korea, 2010.

[11] K.-J. Song, Z. G. Kim, C. I. Zhang, and Y. H. Kim, "Fishing gears involved in entanglements of minke whales (Balaenoptera acutorostrata) in the East Sea of Korea," Marine Mammal Science, vol. 26, no. 2, pp. 282-295, 2010.

[12] C. I. Zhang, K.-J. Song, and J.-H. Na, "Estimation of mortality coefficients and survivorship curves for minke whales (Balaenoptera acutorostrata) in Korean waters," Animal Cells and Systems, vol. 14, no. 4, pp. 291-296, 2010.

[13] K.-J. Song, "Status of J stock minke whales (Balaenoptera acutorostrata)," Animal Cells and Systems, vol. 15, no. 1, pp. 7984, 2011.

[14] K. J. Song, "Potential areas for whale watching in Korean waters," Tourism in Marine Environments, vol. 8, no. 4, pp. 213219, 2013.

[15] K. J. Song, "Potential collision risks of large whales and fast ferries traveling between Korea and Japan," Journal of Marine Animals and Their Ecology, vol. 6, no. 1, pp. 6-10, 2013.

[16] D. W. Weller, A. M. Burdin, B. Würsig, B. L. Taylor, and R. L. Brownell Jr., "The western gray whale: a review of past exploitation, current status and potential threats," Journal of Cetacean Research and Management, vol. 4, no. 1, pp. 7-12, 2002. 

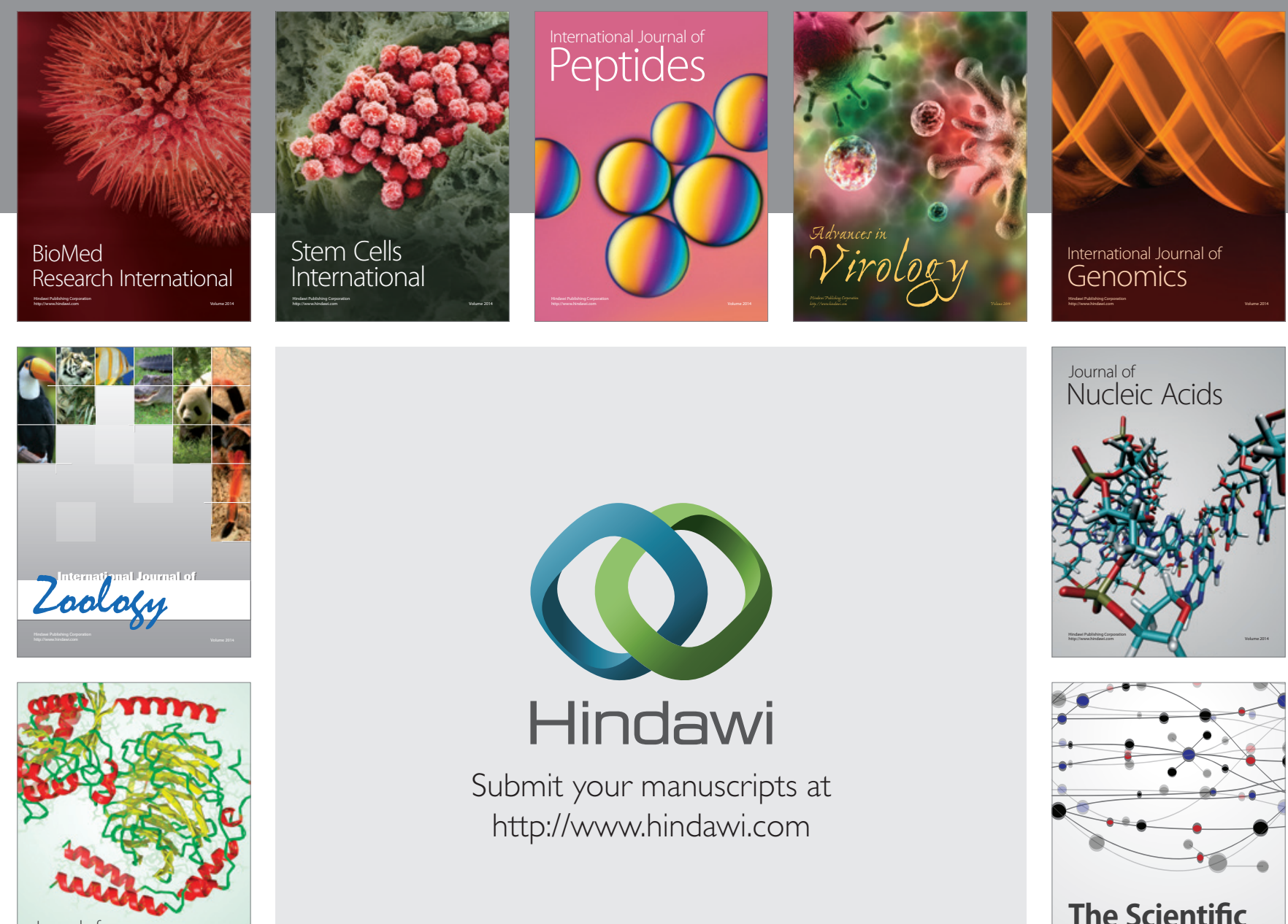

Submit your manuscripts at

http://www.hindawi.com

Journal of
Signal Transduction
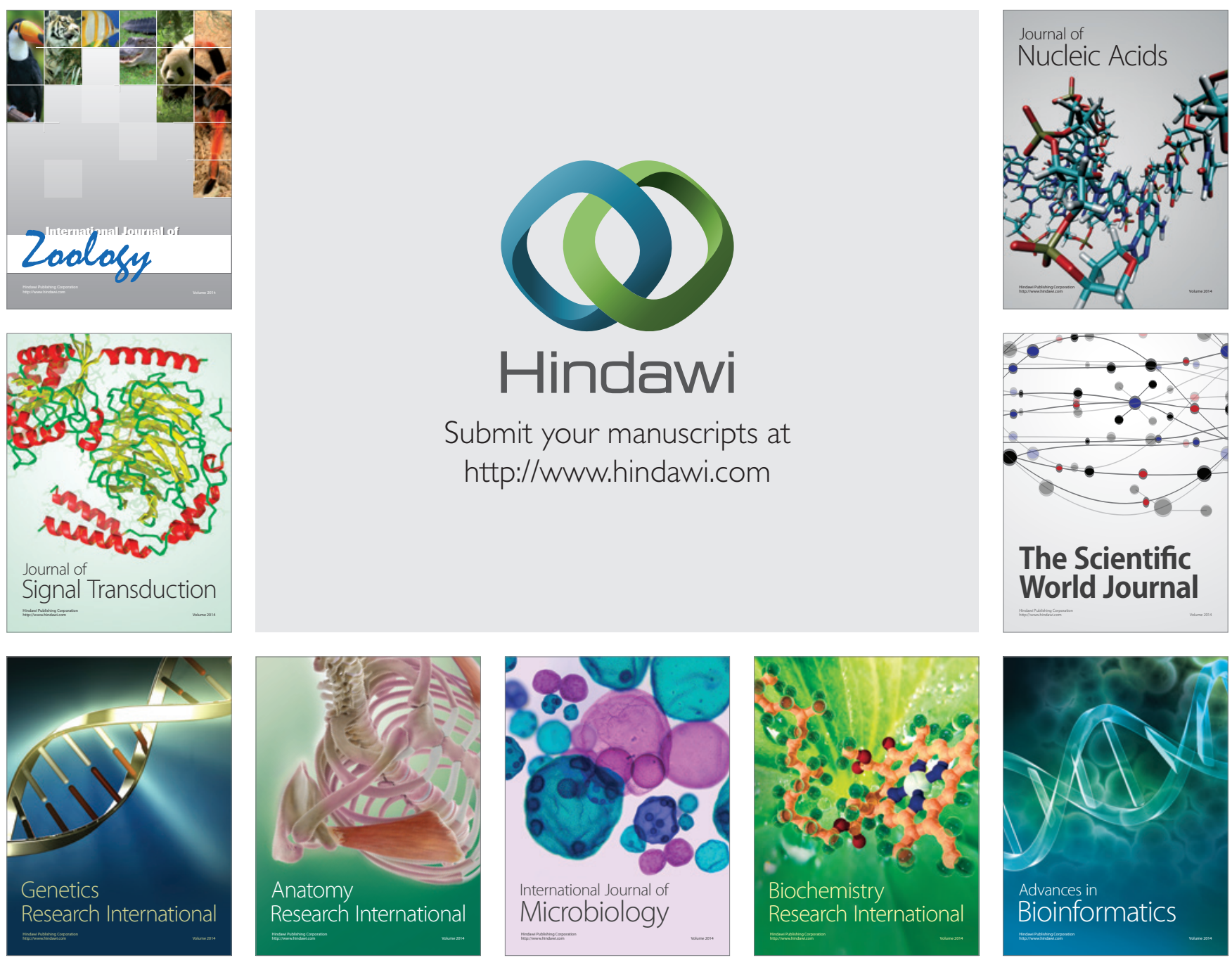

The Scientific World Journal
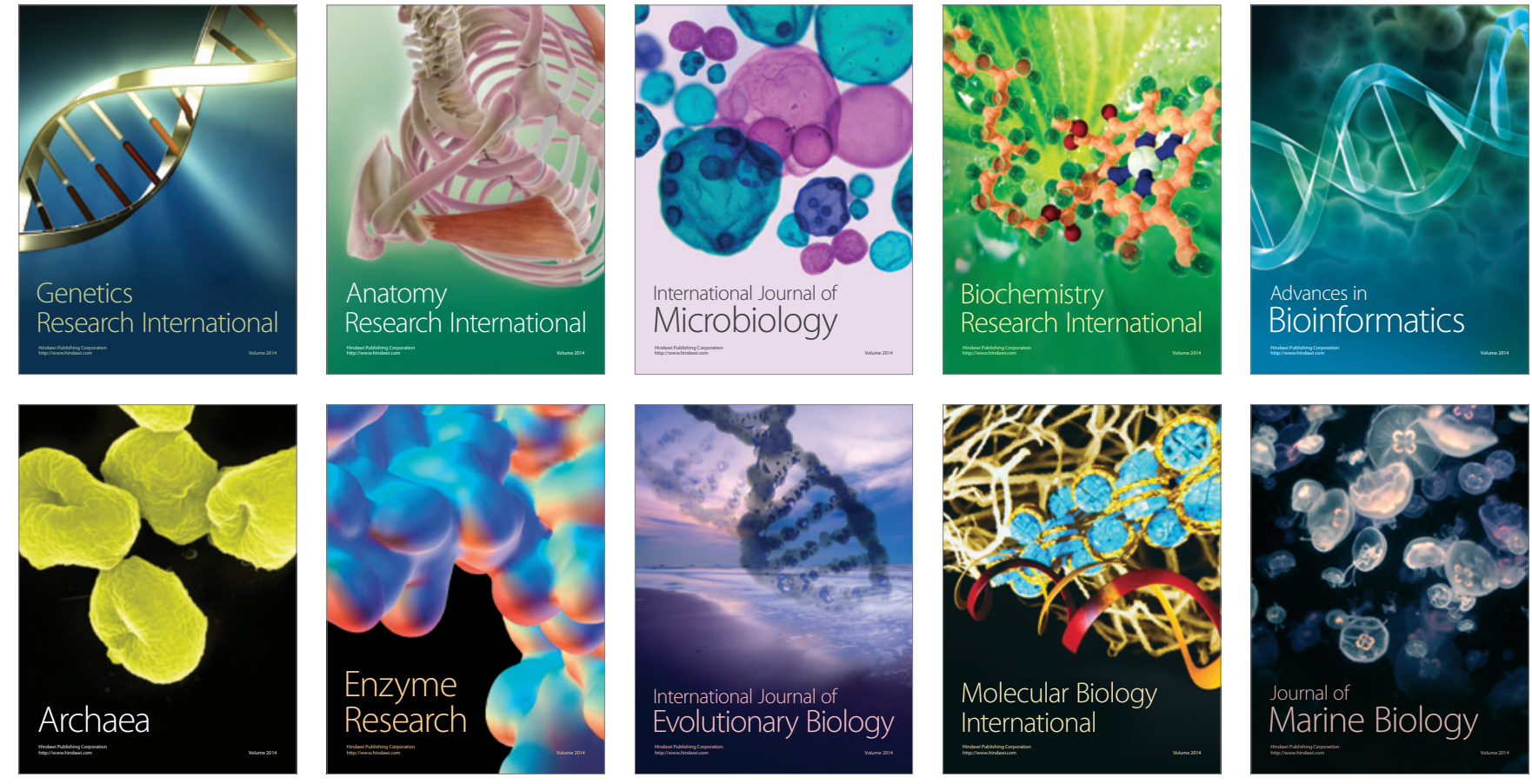